\title{
Use of Enzymatic Bio-Fenton as a New Approach in Decolorization of Malachite Green
}

\author{
Afzal Karimi, ${ }^{1,2}$ Mostafa Aghbolaghy, ${ }^{1}$ Alireza Khataee, ${ }^{2}$ and Shabnam Shoa Bargh ${ }^{1}$ \\ ${ }^{1}$ Department of Chemical Engineering, University of Tabriz, Tabriz 51666-17615, Iran \\ ${ }^{2}$ Department of Applied Chemistry, University of Tabriz, Tabriz 51666-17615, Iran
}

Correspondence should be addressed to Afzal Karimi, akarimi@tabrizu.ac.ir

Received 30 October 2011; Accepted 12 January 2012

Academic Editors: J. Canário, G.-C. Fang, and P. J. Lasier

Copyright ( $) 2012$ Afzal Karimi et al. This is an open access article distributed under the Creative Commons Attribution License, which permits unrestricted use, distribution, and reproduction in any medium, provided the original work is properly cited.

\begin{abstract}
An enzymatic reaction using glucose oxidase was applied for in situ production of hydrogen peroxide for use in simultaneously Fenton's reaction in decolorization of malachite green. It was found that decolorization rate increased by increasing of glucose concentration from $0.2 \mathrm{~g} / \mathrm{L}$ to $1.5 \mathrm{~g} / \mathrm{L}$. Decolorization rate showed different behaviors versus temperature changes. Initial rate of decolorization process was increased by increasing of temperature; after 30 minutes, especially at temperatures above $30^{\circ} \mathrm{C}$, the decolorization rate was gradually reduced. The $\mathrm{pH}$ value in the reaction media was decreased from natural to about $\mathrm{pH}=3 \mathrm{which}$ had synergic effect on the Fenton process by stabilizing of $\mathrm{Fe}^{2+}$ ions.
\end{abstract}

\section{Introduction}

Releasing of chemical wastes into the environment has caused a variety of environmental problems. Some of the important industrial pollutants are dyes. Dyestuffs are vastly used in the textile, cosmetics, paper, leather, plastics, pharmaceutical, and food industries $[1,2]$. The textile industry accounts approximately two-thirds of total dyestuff market [3], and it is estimated that as much as $2-50 \%$ of applied dyestuff may be lost to wastewater which is finally released into environment $[4,5]$. Dyeing materials are major sources of environmental contamination, especially for water pollution [6]. Therefore, the removal of dyestuffs from waste effluents becomes environmentally important. However, there is no simple and economical method for color removal from textile effluents. Many methods such as ozonation, photooxidation, electrocoagulation, adsorption, activated carbon, froth flotation, reverse osmosis, ion exchange, membrane filtration, and flocculation have been tested for removing of color from textile effluents [7-9]. Nevertheless, expensive plant requirements, high operational costs, regeneration problem, secondary pollutants, sensitivity to variations in wastewater input, interference by other wastewater constituents, and residual sludge generation are some technological and economical disadvantages of these methods [10-14].

Malachite green (MG) belongs to triphenyl methane dyes and is the most applicable material in dyeing industry [15]. It is known that MG has damaging effects on ecosystem and its releasing into aqueous streams will affect aquatic life and cause impairing effects in liver, kidney, intestine, and gonads $[10,16]$. In addition, $M G$ is tumor promoter to human beings and contact of MG with skin causes irritation, redness, and pain $[17,18]$. Therefore, removing of MG from contaminated effluents is necessary for ecosystem and human health.

Although conventional decolorization processes are not suitable enough, biological methods are attractive alternatives which have received increasing interest owing to their cost, effectiveness, selectivity, capability of complete degradation of organic pollutants, and in situ use [4, 20-22]. On the other hand, Fenton's reaction is a well-known and powerful method for oxidation of organic pollutants [23]. In this reaction, ferrous ion reacts with hydrogen peroxide to produce hydroxyl radical through the following equation [24]:

$$
\mathrm{Fe}^{2+}+\mathrm{H}_{2} \mathrm{O}_{2} \longrightarrow \mathrm{Fe}^{3+}+\mathrm{HO}^{\bullet}+\mathrm{HO}^{-} \text {. }
$$




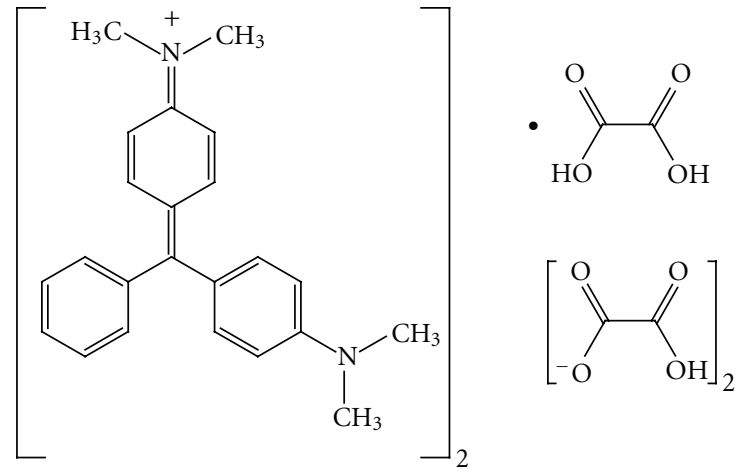

FIGURE 1: chemical structure of malachite green [19].

Hydroxyl radicals have powerful oxidizing potential $\left(\mathrm{E}^{\circ}=\right.$ $2.8 \mathrm{~V}$ ), so they can easily oxidize a wide diversity of organic materials [25]. As have been reported in literatures, Fenton's reaction has been used to treat various wastewaters containing dyestuffs [26-28].

In this study, the feasibility of bio-Fenton reaction, which is a novel approach in decolorization of MG, was investigated. A new simple enzymatic reaction, catalyzed by glucose oxidase $\left(\mathrm{GO}_{\mathrm{X}}\right)$, was applied for in situ production of hydrogen peroxide and simultaneously Fenton's reaction performed for decolorization of the dye. The effects of various factors including substrate concentration, initial dye concentration, and temperature on the efficiency of bioFenton reaction in the removing of $M G$ from aqueous solution were investigated. In addition, variation of $\mathrm{pH}$ in bio-Fenton process and its effect on MG decolorization were monitored.

\section{Materials and Methods}

2.1. Materials. Glucose oxidase $\left(\mathrm{GO}_{\mathrm{X}}\right)$ type II (EC 1.1.3.4, 25 $\mathrm{U} / \mathrm{mg}$, from Aspergillus niger), $\beta$-D-(+)-glucose, $2,2^{\prime}$-Azinodi-[3-ethylbenzthiazoline sulfonate], $\mathrm{FeSO}_{4}$, and malachite green oxalate (MG) were obtained from Sigma Aldrich. The chemical structure of the dye has been represented in Figure 1. All chemicals were of analytical grade, and deionized water was used in preparation of solutions.

2.2. Dye Concentration Analysis. The concentration of MG in sample solutions was determined by measuring its absorbance with spectrophotometer (UV/Vis spectrophotometer WPA light wave S2000) at maximum absorption wavelengths of the dye $\left(\lambda_{\max }=619 \mathrm{~nm}\right)$. Different standard solutions were used to plot absorbance calibration curve, which is shown in Figure 2.

As has been shown in Figure 3, the absorbance spectrum of reaction solution without MG is different enough from absorbance pick of aquatic solution of MG, so concentration of MG can be measured accurately.

The decolorization efficiency was calculated through

$$
R(\%)=\left(\frac{C_{0}-C_{t}}{C_{0}}\right) \times 100
$$

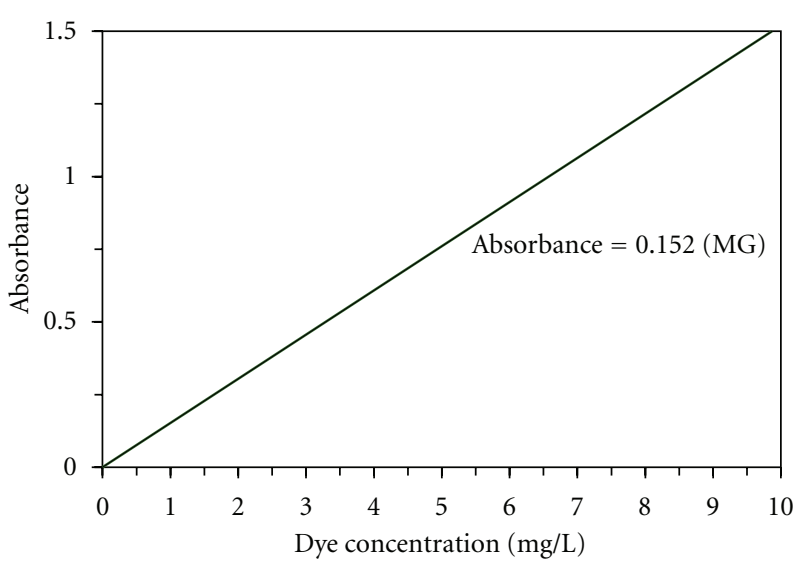

FIgURE 2: Calibration curve.

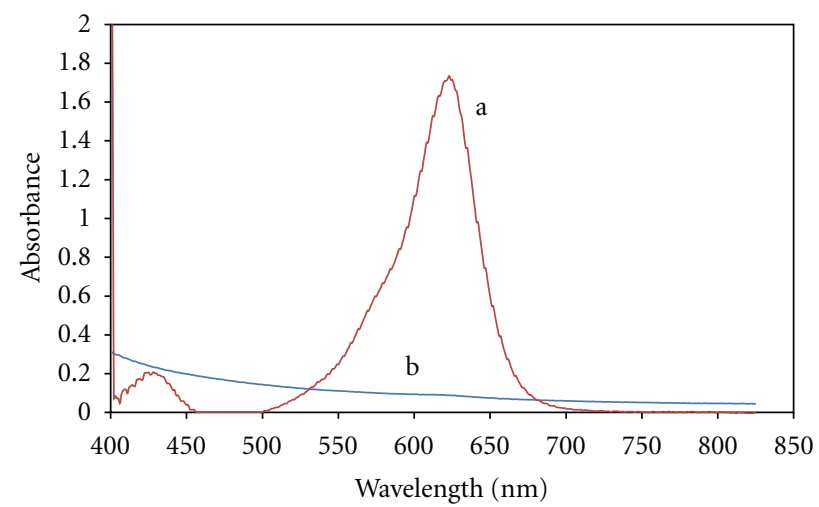

FIGURE 3: Absorbance spectrum: (a); aquatic solution of MG (b); aquatic solution of glucose, glucose oxidase and $\mathrm{Fe}^{2+}$.

where $C_{0}$ is the initial concentration of $M G(\mathrm{mg} / \mathrm{L})$ and $C$ is the concentration of $\mathrm{MG}(\mathrm{mg} / \mathrm{L})$ at time $t(\mathrm{~min})$.

The decolorization rate was also calculated by (3).

$$
r=\left(\frac{(\text { color removal \% })_{t_{2}}-(\text { color removal \% })_{t_{1}}}{t_{2}-t_{1}}\right) * C_{0} .
$$

2.3. Assay of $\mathrm{GO}_{X}$ Activity. In the presence of oxygen, $\mathrm{GO}_{\mathrm{X}}$ oxidizes $\beta$-D-glucose to $\beta$-D-glucono- $\delta$-lactone and $\mathrm{H}_{2} \mathrm{O}_{2}$. The produced $\mathrm{H}_{2} \mathrm{O}_{2}$ is then utilized to oxidize a chromogenic substrate in the presence of catalase. 2,2'-Azino-di-[3ethylbenzthiazoline sulfonate] was used for monitoring color change through forming a greenish-blue oxidized product that was measured spectrophotometrically at $420 \mathrm{~nm}$. One unit of catalyst activity $(\mathrm{U})$ is defined as the amount of $\mathrm{GO}_{\mathrm{X}}$ required to consume $1 \mu \mathrm{mol}$ substrate in one $\min$ at $25^{\circ} \mathrm{C}$ [29].

2.4. Experimental Procedures. Experiments were performed in $250 \mathrm{~mL}$ Erlenmeyer flasks containing $50 \mathrm{~mL}$ of reaction mixtures at constant shaking rate of $160 \mathrm{r} / \mathrm{min}$. Reaction mixtures were prepared by desired amounts of MG, glucose oxidase, glucose, and $\mathrm{FeSO}_{4}$ in distilled water. The effects of 


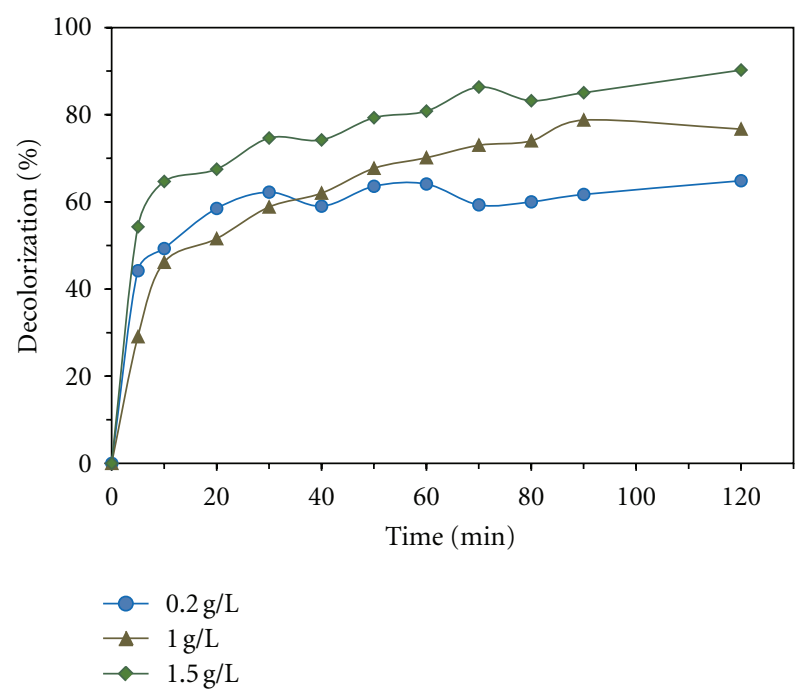

FIgURE 4: Decolorization percentage at various concentrations of glucose at $[\mathrm{MG}]_{0}=15 \mathrm{mg} / \mathrm{L}$, $[\text { enzyme }]_{0}=1000 \mathrm{U} / \mathrm{L},\left[\mathrm{Fe}^{2+}\right]_{0}=10 \mathrm{mM}$, and $\mathrm{T}=30^{\circ} \mathrm{C}$.

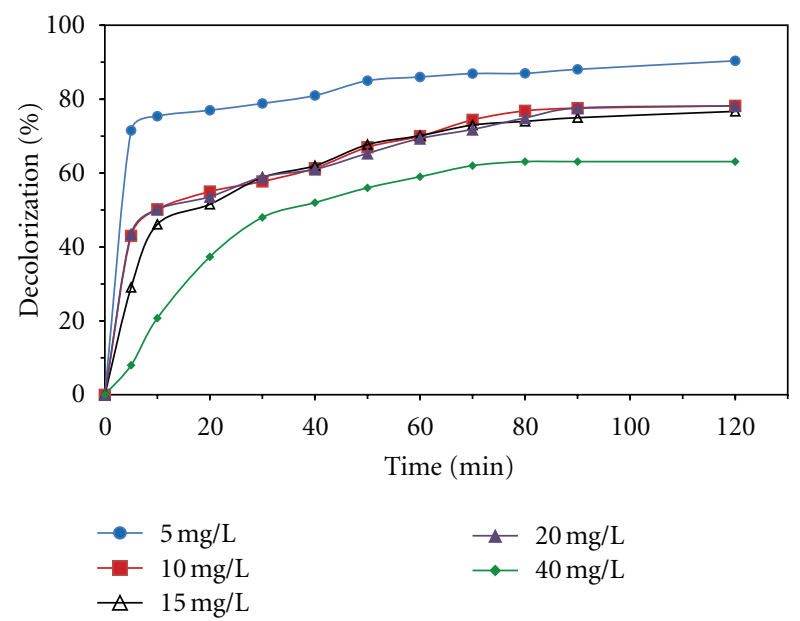

FIgURe 5: Decolorization percentage at various concentrations of MG at $[\text { Glucose }]_{0}=1 \mathrm{~g} / \mathrm{L}$, [enzyme $]_{0}=1000 \mathrm{U} / \mathrm{L},\left[\mathrm{Fe}^{2+}\right]_{0}=10 \mathrm{mM}$, and $\mathrm{T}=30^{\circ} \mathrm{C}$.

glucose concentration $(0.2-1.5 \mathrm{~g} / \mathrm{L})$, MG concentration (5$40 \mathrm{mg} / \mathrm{L})$ and temperature $\left(15-40^{\circ} \mathrm{C}\right)$, on the efficiency of bio-Fenton decolorization process were studied without any control on $\mathrm{pH}$ value.

\section{Results and Discussion}

3.1. Bio-Fenton Process. In this process, glucose oxidase in presence of glucose was applied for in situ production of hydrogen peroxide through (4) and simultaneously hydroxyl

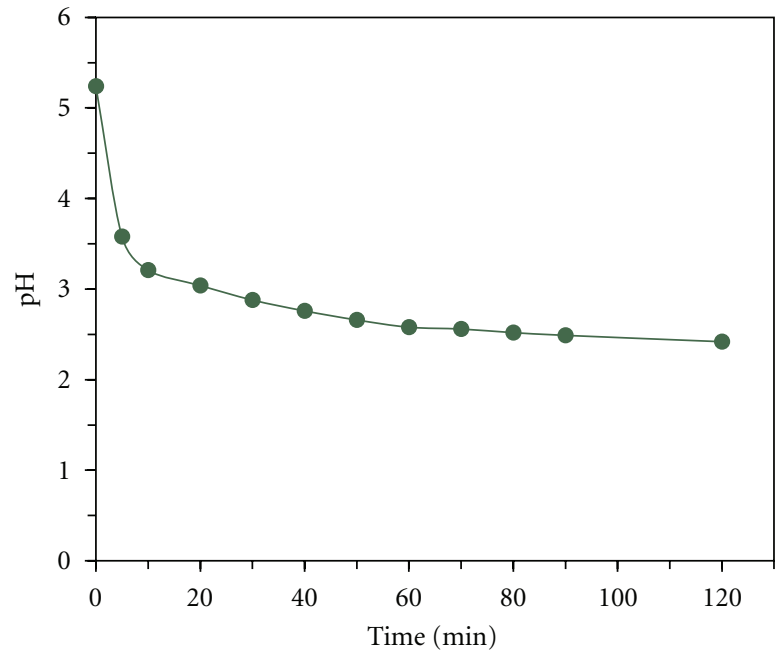

FIgURE 6: Variation of $\mathrm{pH}$ with time in experiments.

radicals producing from Fenton's reaction were used for decolorization of MG through

$$
\begin{gathered}
\mathrm{C}_{6} \mathrm{H}_{12} \mathrm{O}_{6}+\mathrm{H}_{2} \mathrm{O}+\mathrm{O}_{2} \stackrel{\mathrm{GO}_{\mathrm{X}}}{\longrightarrow} \mathrm{C}_{6} \mathrm{H}_{12} \mathrm{O}_{7}+\mathrm{H}_{2} \mathrm{O}_{2} \\
\mathrm{Fe}^{2+}+\mathrm{H}_{2} \mathrm{O}_{2} \longrightarrow \mathrm{Fe}^{3+}+\mathrm{HO}^{\bullet}+\mathrm{HO}^{-} .
\end{gathered}
$$

3.2. Effect of Glucose Concentration. As can be seen in (4), production of hydrogen peroxide is dependent on glucose concentration. For study of the effect of glucose concentration on decolorization rate, different concentrations of glucose $(0.2,1$, and $1.5 \mathrm{~g} / \mathrm{L})$ were tested. This experiments was conducted at initial MG concentration of $15 \mathrm{mg} / \mathrm{L}$, $1000 \mathrm{U} / \mathrm{L}$ enzyme, and $10 \mathrm{mM}\left[\mathrm{Fe}^{2+}\right]_{0}$ at $30^{\circ} \mathrm{C}$. As can be seen in Figure 4, increasing in glucose concentration has caused increasing in decolorization rate. Because of gradual production and immediate consumption of hydrogen peroxide in bio-Fenton process, undesired reactions such as scavenging effect of $\mathrm{H}_{2} \mathrm{O}_{2}$ (5)-(8) could not be conducted at low or medium concentrations of $\mathrm{H}_{2} \mathrm{O}_{2}$ [30]

$$
\begin{gathered}
\mathrm{H}_{2} \mathrm{O}_{2}+\mathrm{OH}^{\bullet} \longrightarrow \mathrm{HO}_{2}^{\bullet}+\mathrm{H}_{2} \mathrm{O} \\
\mathrm{H}_{2} \mathrm{O}_{2}+\mathrm{OH}_{2}^{\bullet} \longrightarrow \mathrm{OH}^{\bullet}+\mathrm{O}_{2}+\mathrm{H}_{2} \mathrm{O} \\
\mathrm{OH}^{\bullet}+\mathrm{OH}_{2} \longrightarrow \mathrm{O}_{2}+\mathrm{H}_{2} \mathrm{O} .
\end{gathered}
$$

3.3. Effect of Initial MG Concentration. Effect of initial MG concentration on decolorization process was tested using different initial concentrations of MG $(5,10,15,20$, and $40 \mathrm{mg} / \mathrm{L}$ ). This experiment was conducted at glucose concentration of $1 \mathrm{~g} / \mathrm{L}, 1000 \mathrm{U} / \mathrm{L}$ enzyme, and $10 \mathrm{mM}\left[\mathrm{Fe}^{2+}\right]_{0}$ at $30^{\circ} \mathrm{C}$. The results have been shown in Figure 5. As can be seen, by increasing the initial MG concentration, decolorization efficacy decreased. But in terms of decolorization rates, which have been reported in Table 1, it is observed that decolorization rate at various periods of time was maximum for initial MG concentration of $40 \mathrm{mg} / \mathrm{L}$ and was minimum for $5 \mathrm{mg} / \mathrm{L}$. It is mainly because there are high 
TABLE 1: Decolorization rate $(\mathrm{mg} / \mathrm{L} \cdot \mathrm{min})$ at different initial concentrations of MG at $[\text { Glucose }]_{0}=1 \mathrm{~g} / \mathrm{L},[\text { enzyme }]_{0}=1000 \mathrm{U} / \mathrm{L},\left[\mathrm{Fe}^{2+}\right]_{0}$ $=10 \mathrm{mM}$, and $\mathrm{T}=30^{\circ} \mathrm{C}$.

\begin{tabular}{lccccc}
\hline \multirow{2}{*}{ Time $(\mathrm{min})$} & \multicolumn{5}{c}{ Decolorization rate $(\mathrm{mg} / \mathrm{L} \cdot \mathrm{min})$} \\
& 5 & 10 & 15 & 20 & 40 \\
\hline $0-20$ & 19.25 & 27.50 & 38.67 & 53.60 & 74.68 \\
$0-60$ & 7.17 & 11.67 & 17.53 & 23.12 & 39.34 \\
$0-120$ & 3.77 & 6.52 & 9.59 & 13.03 & 21.04 \\
$20-60$ & 1.12 & 3.75 & 6.96 & 7.87 & 21.66 \\
\hline
\end{tabular}

TABle 2: Decolorization rate $(\mathrm{mg} / \mathrm{L} \cdot \mathrm{min})$ at different temperatures at $[\mathrm{MG}]_{0}=15 \mathrm{mg} / \mathrm{L},[\text { Glucose }]_{0}=1 \mathrm{~g} / \mathrm{L}$, [enzyme $]_{0}=1000 \mathrm{U} / \mathrm{L}$ and $\left[\mathrm{Fe}^{2+}\right]_{0}=10 \mathrm{mM}$.

\begin{tabular}{|c|c|c|c|c|}
\hline \multirow[t]{2}{*}{ Time $(\min )$} & \multicolumn{4}{|c|}{$\begin{array}{c}\text { Decolorization rate }(\mathrm{mg} / \mathrm{L} \cdot \mathrm{min}) \\
\text { at temperatures }\left({ }^{\circ} \mathrm{C}\right) \text { of }\end{array}$} \\
\hline & 15 & 30 & 35 & 40 \\
\hline $0-20$ & 30.51 & 38.68 & 37.50 & 40.035 \\
\hline $0-60$ & 17.65 & 17.53 & 17.37 & 17.48 \\
\hline $0-120$ & 9.55 & 9.59 & 8.90 & 8.36 \\
\hline
\end{tabular}

numbers of dye molecules in high concentration of MG while other conditions are constant. The other reason is the fast consumption of hydroxyl radicals in high concentrations of the dye, so probability of undesired reactions of radicals is low.

3.4. Effect of Temperature. The effect of temperature on decolorization process was performed at $15,30,35$ and $40^{\circ} \mathrm{C}$ This experiment was conducted at initial MG concentration of $15 \mathrm{mg} / \mathrm{L}$, glucose concentration of $1 \mathrm{~g} / \mathrm{L}, 1000 \mathrm{U} / \mathrm{L}$ enzyme, and $10 \mathrm{mM}\left[\mathrm{Fe}^{2+}\right]_{0}$. The results have been shown in Table 2. In higher temperatures, initial decolorization is faster because of acceleration of hydrogen peroxide reaction with $\mathrm{Fe}^{2+}[19]$. However, decolorization rate decreased at temperatures above $30^{\circ} \mathrm{C}$ after $30 \mathrm{~min}$. This may be due to deactivation of several active sites of the enzyme because of denaturation of protein molecules by heating and therefore decreasing of in-situ hydrogen peroxide production rate.

3.5. $p H$ Trend in the Reaction Media. The variation of $\mathrm{pH}$ value was similar in all experiments and has been illustrated in Figure 6. The $\mathrm{pH}$ value in the reaction media was decreased from natural to about 3 which had synergic effect on Fenton process by stabilizing of $\mathrm{Fe}^{2+}$ ions. For determination of $\mathrm{pH}$ effect on MG concentration without bio-Fenton reaction, $\mathrm{pHs}$ of $\mathrm{MG}$ solutions with initial concentration of $15 \mathrm{mg} / \mathrm{L}$ were adjusted at $2.5,3.5,4.5$, and 5.5 values. After 120 minutes decolorization of the samples was negligible.

\section{Conclusion}

In this study a new bio-Fenton process, involving enzymatic in-situ generation of $\mathrm{H}_{2} \mathrm{O}_{2}$, was developed for $\mathrm{MG}$ decolorization. Influence of several effective parameters on bio-Fenton process was investigated. It was found that bioFenton process was an efficient, simpler, and safe method for decolorization of MG. Decolorization of the dye was observed to be up to \%78 during $120 \mathrm{~min}$ at the dye concentration of $20 \mathrm{mg} / \mathrm{L}$ without taking any control on $\mathrm{pH}$.

\section{References}

[1] M. Dogan, H. Abak, and M. Alkan, "Adsorption of methylene blue onto hazelnut shell: kinetics, mechanism and activation parameters," Journal of Hazardous Materials, vol. 164, no. 1, pp. 172-181, 2009.

[2] R. O. Cristóvão, A. P. M. Tavares, J. M. Loureiro, R. A. R. Boaventura, and E. A. Macedo, "Treatment and kinetic modelling of a simulated dye house effluent by enzymatic catalysis," Bioresource Technology, vol. 100, no. 24, pp. 62366242, 2009.

[3] S. Asad, M. A. Amoozegar, A. A. Pourbabaee, M. N. Sarbolouki, and S. M. M. Dastgheib, "Decolorization of textile azo dyes by newly isolated halophilic and halotolerant bacteria," Bioresource Technology, vol. 98, no. 11, pp. 20822088, 2007.

[4] A. B. Dos Santos, F. J. Cervantes, and J. B. van Lier, "Review paper on current technologies for decolourisation of textile wastewaters: perspectives for anaerobic biotechnology," Bioresource Technology, vol. 98, no. 12, pp. 2369-2385, 2007.

[5] E. Forgacs, T. Cserhati, and G. Oros, "Removal of synthetic dyes from wastewaters: a review," Environment International, vol. 30, no. 7, pp. 953-971, 2004.

[6] J. H. Sun, S. H. Shi, Y. F. Lee, and S. P. Sun, "Fenton oxidative decolorization of the azo dye direct blue 15 in aqueous solution," Chemical Engineering Journal, vol. 155, no. 3, pp. 680-683, 2009.

[7] A. Aleboyeh, M. B. Kasiri, M. E. Olya, and H. Aleboyeh, "Prediction of azo dye decolorization by $\mathrm{UV} / \mathrm{H}_{2} \mathrm{O}_{2}$ using artificial neural networks," Dyes and Pigments, vol. 77, no. 2, pp. 288-294, 2008.

[8] N. Daneshvar, D. Salari, and A. R. Khataee, "Photocatalytic degradation of azo dye acid red 14 in water on $\mathrm{ZnO}$ as an alternative catalyst to $\mathrm{TiO}_{2}$," Journal of Photochemistry and Photobiology A, vol. 162, no. 2-3, pp. 317-322, 2004.

[9] A. R. Khataee, V. Vatanpour, and A. R. Amani Ghadim, "Decolorization of C.I. acid blue 9 solution by UV/Nano$\mathrm{TiO}_{2}$, fenton, fenton-like, electro-fenton and electrocoagulation processes: a comparative study," Journal of Hazardous Materials, vol. 161, no. 2-3, pp. 1225-1233, 2009.

[10] N. Daneshvar, M. Ayazloo, A. R. Khataee, and M. Pourhassan, "Biological decolorization of dye solution containing malachite green by microalgae Cosmarium sp," Bioresource Technology, vol. 98, no. 6, pp. 1176-1182, 2007.

[11] S. Ertugrul, N. O. San, and G. Donmez, "Treatment of dye (Remazol Blue) and heavy metals using yeast cells with the purpose of managing polluted textile wastewaters," Ecological Engineering, vol. 35, no. 1, pp. 128-134, 2009.

[12] P. Kaushik and A. Malik, "Fungal dye decolourization: recent advances and future potential," Environment International, vol. 35 , no. 1, pp. 127-141, 2009. 
[13] I. M. Banat, P. Nigam, and D. Singh, "Microbial decolorization of textile-dye-containing effluents: a review," Bioresource Technology, vol. 58, no. 3, pp. 217-227, 1996.

[14] Z. Aksu, "Application of biosorption for the removal of organic pollutants: a review," Process Biochemistry, vol. 40, no. 3-4, pp. 997-1026, 2005.

[15] V. K. Gupta, A. Mittal, L. Krishnan, and V. Gajbe, "Adsorption kinetics and column operations for the removal and recovery of malachite green from wastewater using bottom ash," Separation and Purification Technology, vol. 40, no. 1, pp. 8796, 2004.

[16] S. Srivastava, R. Sinha, and D. Roy, "Toxicological effects of malachite green," Aquatic Toxicology, vol. 66, no. 3, pp. 319329,2004

[17] K. Vasanth Kumar, V. Ramamurthi, and S. Sivanesan, "Biosorption of malachite green, a cationic dye onto Pithophora sp., a fresh water algae," Dyes and Pigments, vol. 69, no. 1-2, pp. 74-79, 2006.

[18] K. V. Kumar, S. Sivanesan, and V. Ramamurthi, "Adsorption of malachite green onto Pithophora sp., a fresh water algae: equilibrium and kinetic modelling," Process Biochemistry, vol. 40, no. 8, pp. 2865-2872, 2005.

[19] B. H. Hameed and T. W. Lee, "Degradation of malachite green in aqueous solution by fenton process," Journal of Hazardous Materials, vol. 164, no. 2-3, pp. 468-472, 2009.

[20] K. C. Chen, J. Y. Wu, D. J. Liou, and S. C. J. Hwang, "Decolorization of the textile dyes by newly isolated bacterial strains," Journal of Biotechnology, vol. 101, no. 1, pp. 57-68, 2003.

[21] G. Arroyo-Figueroa, G. M. L. Ruiz-Aguilar, L. LópezMartínez, G. González-Sánchez, G. Cuevas-Rodríguez, and R. Rodríguez-Vázquez, "Treatment of a textile effluent from dyeing with cochineal extracts using Trametes versicolor fungus," The Scientific World Journal, vol. 11, pp. 1005-1016, 2011.

[22] A. Anastasi, F. Spina, V. Prigione, V. Tigini, P. Giansanti, and G. C. Varese, "Scale-up of a bioprocess for textile wastewater treatment using Bjerkandera adusta," Bioresource Technology, vol. 101, no. 9, pp. 3067-3075, 2010.

[23] H. J. H. Fenton, "Oxidation of tartaric acid in presence of iron," Journal of the Chemical Society, vol. 65, pp. 899-910, 1894.

[24] C. Walling, "Fenton's reagent revisited," Accounts of Chemical Research, vol. 8, no. 4, pp. 125-131, 1975.

[25] A. Mofidi, H. Joon, S. Leslie, M. Coffey, S. Liang, and J. Green, Advanced Oxidation Processes and UV Photolysis for Treatment of Drinking Water, Metropolitan Water District of Southern California La Verne, La Verne, Calif, USA, 2002.

[26] A. E. Papadopoulos, D. Fatta, and M. Loizidou, "Development and optimization of dark fenton oxidation for the treatment of textile wastewaters with high organic load," Journal of Hazardous Materials, vol. 146, no. 3, pp. 558-563, 2007.

[27] S. P. Sun, C. J. Li, J. H. Sun, S. H. Shi, M. H. Fan, and Q. Zhou, "Decolorization of an azo dye orange $\mathrm{G}$ in aqueous solution by fenton oxidation process: effect of system parameters and kinetic study," Journal of Hazardous Materials, vol. 161, no. 23, pp. 1052-1057, 2009.

[28] C. W. Li, Y. M. Chen, Y. C. Chiou, and C. K. Liu, "Dye wastewater treated by fenton process with ferrous ions electrolytically generated from iron-containing sludge," Journal of Hazardous Materials, vol. 144, no. 1-2, pp. 570-576, 2007.

[29] S. B. Bankar, M. V. Bule, R. S. Singhal, and L. Ananthanarayan, "Glucose oxidase-an overview," Biotechnology Advances, vol. 27, no. 4, pp. 489-501, 2009.
[30] R. Aravindhan, N. N. Fathima, J. R. Rao, and B. U. Nair, "Wet oxidation of acid brown dye by hydrogen peroxide using heterogeneous catalyst Mn-salen-Y zeolite: a potential catalyst," Journal of Hazardous Materials, vol. 138, no. 1, pp. 152-159, 2006. 

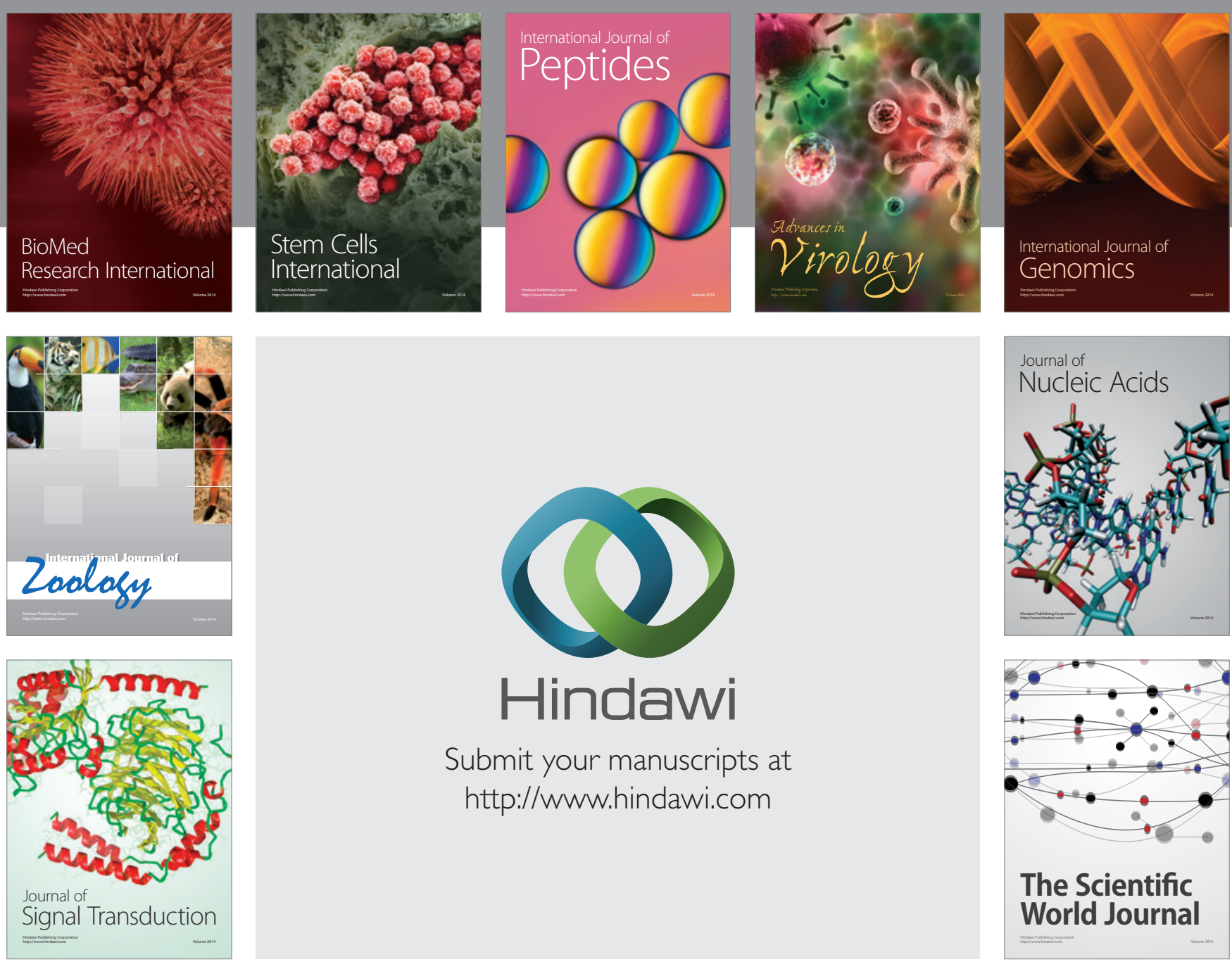

Submit your manuscripts at

http://www.hindawi.com
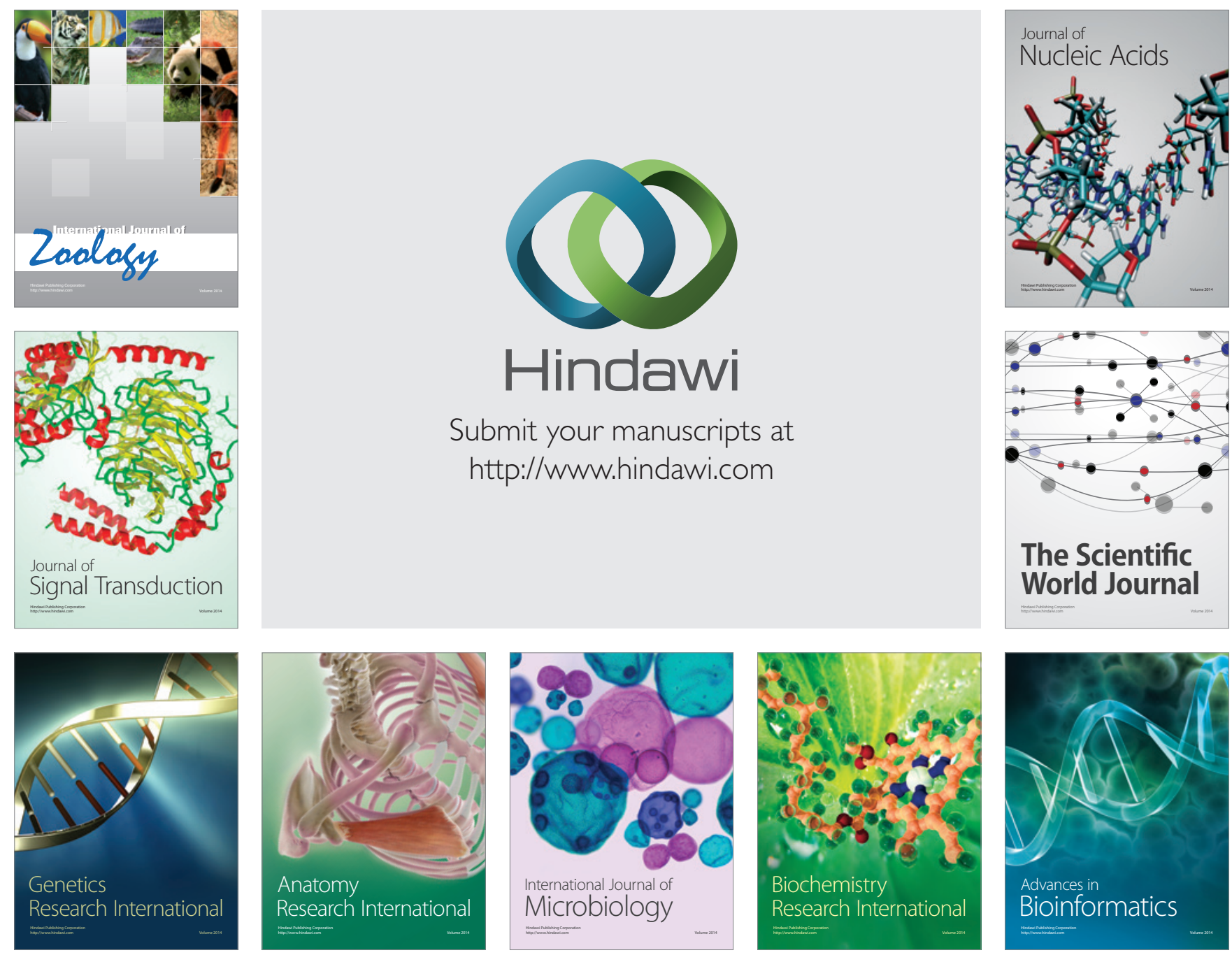

The Scientific World Journal
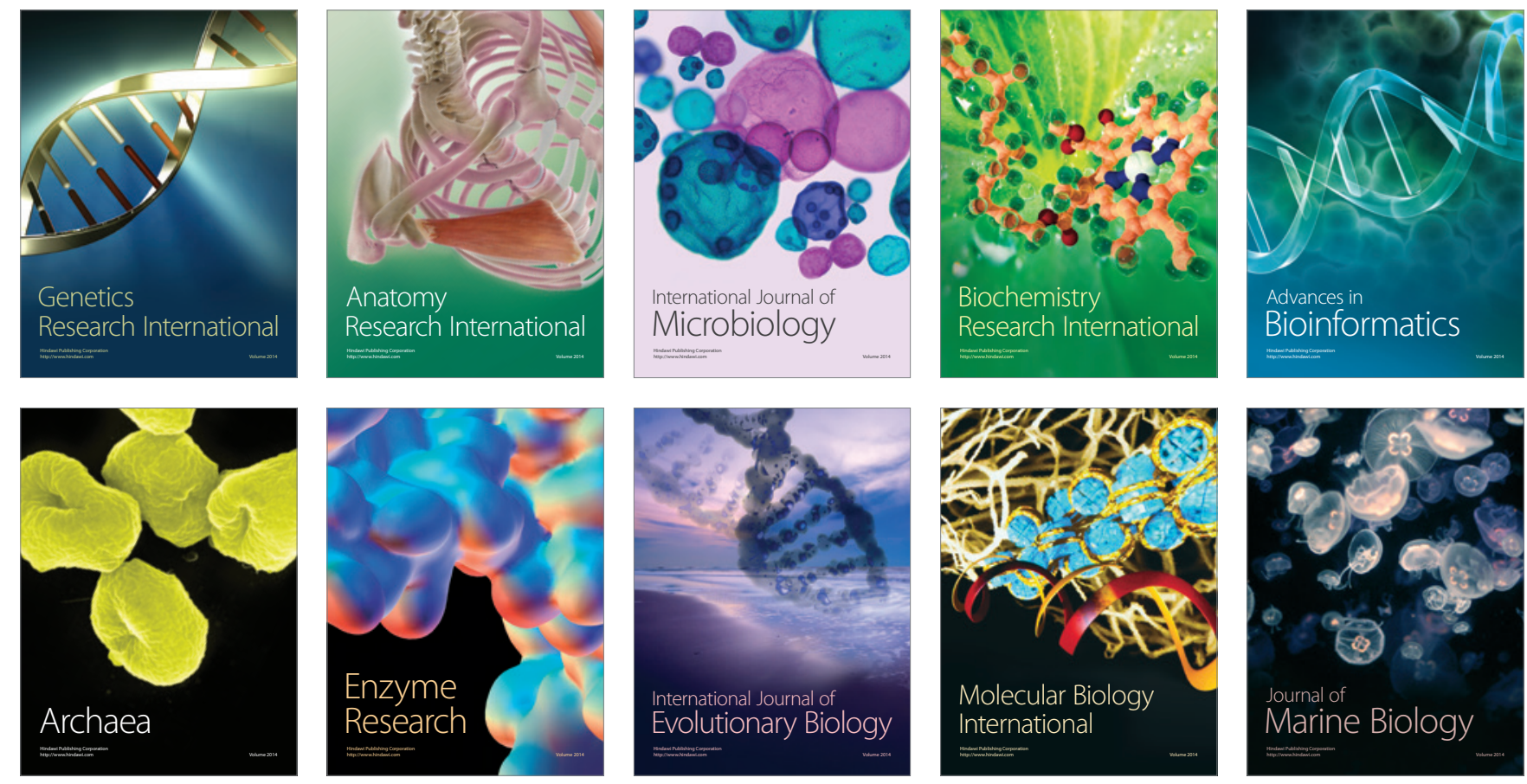